\title{
Sill i päls - 20 år i Putins skugga
}

\author{
Kristoffer Lieng \\ Stockholm: LYS \\ 214 sider. ISBN 9789198438960
}

Omtalt av Morten Jentoft [journalist og forfatter, morten.jentoft@nrk.no]

Kristoffer Lieng har tilbrakt mye av de siste 20 årene i Russland eller med spørsmål som har med Russland å gjøre, blant annet som reporter for både svenske og finske medier, og som lærer i svensk for studenter i Moskva. Gjennom disse årene har han opparbeidet betydelig kunnskap om både språk, historie og levesett hos vår store nabo i øst. Denne kunnskapen har han nå brukt til å skrive boken Sill i päls, som henspiller på den kjente russiske salaten som ofte serveres i forbindelse med jule- og nyttårsfeiringen.

Kristoffer Lieng har en spennende familiebakgrunn, med en farmor som var født i en norsk-latvisk familie i tsarens St. Petersburg, og en farfar fra et lite sted i nærheten av Lillehammer, som søkte lykken i det selvstendige Latvia på 1930-tallet. Der traff han norsk-latviske Gerda, som sammen med sin familie hadde valgt å dra fra det nå kommuniststyrte Russland i 1923. De to valgte, i likhet med mange andre, å forlate Latvia mot slutten av andre verdenskrig og slo seg ned i Sverige. Resten av familien ble igjen i Latvia, der flere ble offer for undertrykkelse og deportasjon etter krigen.

Denne bakgrunnen var nok årsaken til at Kristoffer Lieng tidlig begynte å interessere seg for Russland og endte opp med både studier i russisk og arbeid i den svenskspråklige redaksjonen i Russlands stemme, Radio Moskvas sendinger på svensk. Boken gir oss spennende møter med noen av de ansatte i denne redaksjonen, blant andre legenden Irina Gardenina. Men det er ikke riktig som Lieng skriver, at Tage Erlander i 1956 var den første vestlige statsministeren som var på besøk i Sovjetunionen. Den norske statsministeren Einar Gerhardsen var i Moskva i november 1955, med en annen av medarbeiderne i Radio Moskva, Ksenija Aleksandrova, som en av tolkene. Den tyske forbundskansleren Konrad Adenauer var også i Moskva i september 1955.

Jeg synes også forfatterens besøk i Tsjuvasjia, en av mange republikker innenfor den russiske føderasjonen, der minoriteten tsjuvasjerne sliter med å opprettholde sitt eget språk, er interessant. Bortsett fra noen få unntak, blant annet i republikken Tatarstan, så er mange av minoritetsspråkene i Russland under voldsomt press og står i fare for å dø helt ut. Dette skulle jeg gjerne ha hatt mer av, og det er dessverre 
noe som går igjen i denne boken. Forfatteren gir oss små smakebiter av noe som vi gjerne vil vite mer om. Boken hadde tjent på å gå mer i dybden, både om situasjonen i Tsjuvasjia og om hans egen families historie. Denne siste er verdt en bok i seg selv, og Kristoffer Lieng viser med boken at han kan observere og skrive med innlevelse.

Et sted i boken dukker plutselig Katja i Sotsji opp, som i løpet av kort tid hadde mistet både sin mor, far og morfar, og som i tillegg plutselig får vite at hennes kjæreste Sasja er arrestert etter at han har drept en mann i et fylleslagsmål. Og når hun tar en graviditetstest, er den selvfølgelig positiv. Dramatisk, selvfølgelig, men dette blir hengende litt i løse luften i en bok som dette.

Best er Kristoffer Lieng når han tar oss med inn i russiske tradisjoner, og det gjelder ikke bare til salater som "sill i päls». Han forteller levende om hvordan det er å gifte seg på russisk, og om navneskikker i forbindelse med dåp. Det er ikke alle navn som den russisk-ortodokse kirken vil godta, men kan du putte inn Fillip som mellomnavn etter Einar, ja så går det bra.

Jeg synes også han er bra når han skriver om bildet av Russland i Sverige og Vesten - og andre veien. Alle som har besøkt det moderne Russland under president Vladimir Putin, ser at det er mye som har forandret seg til det bedre. Men samtidig giør ikke Putin og russerne det alltid like lett for seg selv, noe den brutale innblandingen i Ukraina fra 2014 er et godt eksempel på.

Overraskende og positivt er det at Kristoffer Lieng mot slutten av boken gir oss et lite lynkurs i russisk språk, med både uttale og litt om hemmelighetene i det kyrilliske alfabetet. Dette tror jeg det er mange ikke-russiskkyndige som setter pris på, og det kan være en spore til videre studier.

Jeg håper Kristoffer Lieng ikke stopper med denne boken, men gir oss nye fortellinger der han går mer i dybden. 